\title{
PENERAPAN MODEL PEMBELAJARAN PROBLEM BASED LEARNING DITINJAU DARI AKTIVITAS BELAJAR SISWA
}

\author{
Broto Apriliyanto \\ SMA Negeri 1 Wuryantoro, Wonogiri, Jawa Tengah \\ e-mail: apriliyanto.broto@gmail.com
}

\begin{abstract}
Abstrak
Tujuan dari penelitian ini adalah untuk mengetahui : (1) Aktivitas belajar siswa kelas XI IPA SMAN 1 Wuryantoro pada pokok bahasan komposisi fungsi menggunakan model pembelajaran problem based learning. (2) Apakah hasil belajar siswa kelas XI IPA SMAN 1 Wuryantoro pada pokok bahasan komposisi fungsi mengunakan problem based learning dapat meningkat. Penelitian ini merupakan penelitian tindakan kelas. Populasi dalam penelitian ini adalah seluruh siswa kelas XI IPA 1 SMA Negeri 1 Wuryantoro Kabupaten Wonogiri tahun ajaran 2015/2016. Teknik pengumpulan data untuk hasil belajar menggunakan tes, sedangkan untuk aktifitas belajar menggunakan angket dan observasi. Berdasarkan hasil penelitian dapat disimpulkan bahwa : (1) Siswa semakin aktif dalam mengikuti pembelajaran matematika pada pokok bahasan komposisi fungsi menggunakan model pembelajaran problem based learning. (nilai rata-rata aktifitas belajar untuk tahap pra siklus, siklus 1, dan siklus 2 berturut-turut 77, 80, dan 82, sedangkan persentase ketuntasannya berturut-turut 59, 75, dan 84). (2) Hasil belajar siswa kelas XI IPA SMAN 1 Wuryantoro pada pokok bahasan komposisi fungsi mengunakan problem based learning dapat meningkat. (nilai rata-rata hasil belajar untuk tahap pra siklus, siklus 1, dan siklus 2 berturut-turut 73, 75, dan 77, sedangkan persentase ketuntasannya berturut-turut 53,66 , dan 81 ).
\end{abstract}

Kata-kata Kunci: Pembelajaran Problem Based Learning, aktivitas belajar siswa, prestasi belajar.

\section{THE APPLICATION OF PROBLEM BASED LEARNING MODEL BASED ON STUDENT'S LEARNING ACTIVITIES}

\author{
Broto Apriliyanto \\ SMA Negeri 1 Wuryantoro, Wonogiri, Central Java \\ e-mail: apriliyanto.broto@gmail.com
}

\begin{abstract}
Purpose of this study is to determine: (1) Student's activities of XI IPA SMA Negeril Wuryantro on the subject of composition function using problem-based learning model. (2) Whether the student's learning achievement of XI IPA Senior High School 1 Wuryantoro on the subject of composition function can be increased by using problem based learning model. This research is a class action research. The population in this research are all students of XI IPA 1 SMA Negeril Wuryantoro academic year 2015/2016. The data collection technique for learning achievement is by using tests, meanwhile, for the learning activities is by using questionnaires and observations. Based on the results of this study, it can be concluded that: (1) Students are more active in participating in mathematic learning on the subject of composition function using problem-based learning model. (The average value of learning activities for pre-stage cycle, cycle 1 and cycle 2 in a row is 77, 80, and 82, while the percentage of passing grade in a row is 59, 75, and 84). (2) The student's achievement of XI IPA SMA Negeril Wuryantoro on the subject of composition function can be increased by using problem based learning model. (The average value of learning achievement for the pre-stage cycle, cycle 1 and cycle 2 in a row is 73, 75, and 77, while the percentage of passing grade in a row is 53, 66, and 81).
\end{abstract}

Keywords: Problem Based Learning Model, Student's Learning Activity, Math Achievement 


\section{PENDAHULUAN}

Matematika memegang peranan penting dalam berbagai disiplin ilmu dan memajukan daya pikir manusia. Selain itu matematika merupakan ilmu yang universal mendasari perkembangan ilmu dan pengetahuan dan teknologi modern. Mata pelajaran matematika diberikan kepada semua siswa mulai sekolah dasar untuk membekali siswa dengan kemampuan berpikir logis, analitis, sistematis, kritis dan kreatif, serta kemampuan bekerjasama. Berbagai kemampuan tersebut sangat diperlukan untuk melakukan pekerjaan-pekerjaan dan memecahkan permasalahan yang ada dalam kehidupan masyarakat. Oleh sebab itu kemampuan berpikir sangat diperhatikan dalam proses pembelajaran matematika.

Kenyataan di lapangan tentang hasil pembelajaran matematika relatif masih belum sesuai dengan yang diharapkan. Kurangnya keaktifan sering menjadi penghambat pemahaman siswa terhadap materi pelajaran yang seharusnya dikuasai. Siswa masih merasa malas untuk belajar matematika karena dianggapnya terlalu banyak rumus. Mereka menganggap matematika adalah pelajaran yang membosankan karena merasa bingung mengaplikasikan dalam kehidupan seharihari. Trend pendidikan matematika yang berkembang di dunia dewasa ini (Fadjar Shadiq, 2001) dalam Strategi Pembelajaran Matematika SMA (Setiawan, 2008) adalah beralihnya pendidikan matematika dari bentuk formal ke penerapan, proses (activity), dan pemecahan masalah nyata, beralihnya assessment (penilaian) ke bentuk penilaian autentik seperti portofolio, proyek, wawancara (interview), laporan siswa, jurnal penilaian mandiri siswa, ataupun penampilan (performance), pemaduan matematika dengan disiplin lain (dari single diciplines menjadi interdiciplery), peralihan dari belajar perorangan (yang bersifat kompetitif) ke belajar bersama (cooperative learning), peralihan dari belajar menghafal (rote learning) ke belajar pemahaman (learning for understanding) dan belajar pemecahan masalah (problem solving), peralihan dari dasar positivis (behaviorist) ke konstruktivisme, atau dari subject centered ke clearer centered (terbentuk / terkonstruksinya pengetahuan), peralihan dari teori pemindahan pengetahuan (knowledge transmitted) ke bentuk interaktif, investigatif, eksploratif dan kegiatan terbuka, ketrampilan proses, modelling, dan pemecahan masalah

Penggunaan model pembelajaran adalah suatu usaha yang dilakukan oleh guru agar siswa dapat memahami materi dengan maksimal, sehingga setelah melakukan pembelajaran memiliki kompetensi sesuai dengan yang diharapkan. Berbagai macam model pembelajaran yang diimplementasikan mempunyai karakteristik tertentu dengan segala kelebihan dan kekurangan masing-masing. Suatu model baik untuk pokok bahasan dan situasi tertentu, tetapai mungkin tidak tepat untuk yang lain.

Salah satu pokok bahasan dalam palajaran matematika kelas XI SMA Program Ilmu Pengetahuan Alam (IPA) yang sulit dipahami siswa adalah Komposisi Fungsi. Berdasarkan hasil observasi awal diperoleh bahwa siswa mengalami kesulitan ketika mensubstitusikan salah satu fungsi ke fungsi yang lain, apalagi jika berbentuk non 
linear. Siswa akan semakin bingung jika mengadapi lebih dari 2 fungsi. Meskipun mereka terbiasa mensubstitusikan bilangan ke dalam fungsi, namun menjadi hal yang aneh ketika mensubstitusikan fungsi ke dalam fungsi. Siswa merasa hanya menyaksikan operasi aljabar yang tidak bermakna, karena selama ini mereka hanya mengetahui manfaat praktis dari mata pelajaran yang dipelajarainya. Mereka tidak tahu kegunaan atau manfaat yang lebuh mendalam dari materi tersebut, akibatnya mereka tidak mampu memperoleh pengalaman belajar yang seharusnya ia miliki terkait dengan kompetensi tersebut.

Berdasarkan permasalahan di atas perlu sebuah langkah pemecahannya karena materi komposisi fungsi diujikan dalam Ujian Nasional dan soal-soal seleksi masuk perguruan tinggi. Selain itu bentuk komposisi fungsi juga diterapkan dalam transformasi geometri serta bidang matematika yang lain. Pengalaman belajar yang bermakna diharapkan mampu meningkatkan aktifitas belajar siswa untuk berpikir kritis, kreatif dan sistematis. Penulis berusaha memecahkan permasalahan tersebut dengan melakukan penelitian tindakan kelas. Model pembelajaran yang digunakan dalam penelitian ini adalah Problem Based Learning (PBL). Model pembelajaran ini identik dengan pelaksanaan kurikulum 2013 meskipun kurikulum yang digunakan di sekolah adalah KTSP. Pendekatan saintifik dengan pemberian masalah yang aktual serta dapat dipecahkan dengan komposisi fungsi diharapkan menjadikan proses pembelajaran matematika lebih bermakna.

Pada $P B L$, siswa belajar melalui permasalahan-permasalahan praktis yang berhubungan dengan kehidupan nyata. Kemudian siswa diarahkan untuk menyelesaikannya melalui serangkaian pembelajaran yang sistematis. Siswa dituntut mencari informasi dari berbagai sumber sehingga dapat menemukan solusinya serta mampu mengambil kesimpulan berdasarkan pemahaman mereka. Menurut Arends (2008: 43) bahwa esensi $P B L$ menyajikan berbagai situasi yang mengandung permasalahan autentik dan bermakna kepada siswa, sehingga dapat berfungsi sebagai sarana untuk investigasi dan penyelidikan. $P B L$ dirancang untuk membantu siswa mengembangkan keterampilan berpikir dan menyelesaikan masalah, mempelajari peran-peran orang dewasa dan menjadi pelajar yang mandiri. Model ini menjadi pilihan yang menarik bagi guru yang menginginkan pembelajaran yang lebih baik.

\section{METODE PENELITIAN}

Metode yang dilakukan dalam penelitian ini adalah metode Penelitian Tindakan Kelas (PTK). PTK merupakan bentuk kajian sistematis yang reflektif yang dilakukan oleh pelaku tindakan (guru) dan dilakukan untuk memperbaiki kondisi pembelajaran (Subyantoro, 2009:8). Menurut Zainal Aqib (2006:13), penelitian tindakan kelas merupakan suatu pencermatan terhadap kegiatan yang sengaja dimunculkan dan terjadi dalam sebuah kelas. Beradasarkan uraian tersebut dapat disimpulkan bahwa PTK merupakan kajian sistematis yang reflektif dan sengaja dilakukan guru di dalam kelas untuk memperbaiki kondisi pembelajaran.

Penelitian ini dilaksanakan selama 2 bulan yaitu bulan Pebruari sampai dengan Maret tahun 2016. Kegiatan penelitian tindakan kelas 
dilaksanakan pada semester genap karena menyesuaikan materi dan waktu yang disediakan dengan kalender pendidikan di SMA negeri 1 Wuryantoro. Sumber data dalam penelitian ini diperoleh dari data yang berasal subyek penelitian dan bukan subyek penelitian. Sumber data dari subyek penelitian merupakan sumber data primer yang diperoleh dari data nilai ulangan harian dan nilai tugas. Sumber data yang berasal di luar subyek penelitian merupakan sumber data sekunder yaitu sumber data hasil pengamatan yang dilakukan oleh teman sejawat dan angket siswa.

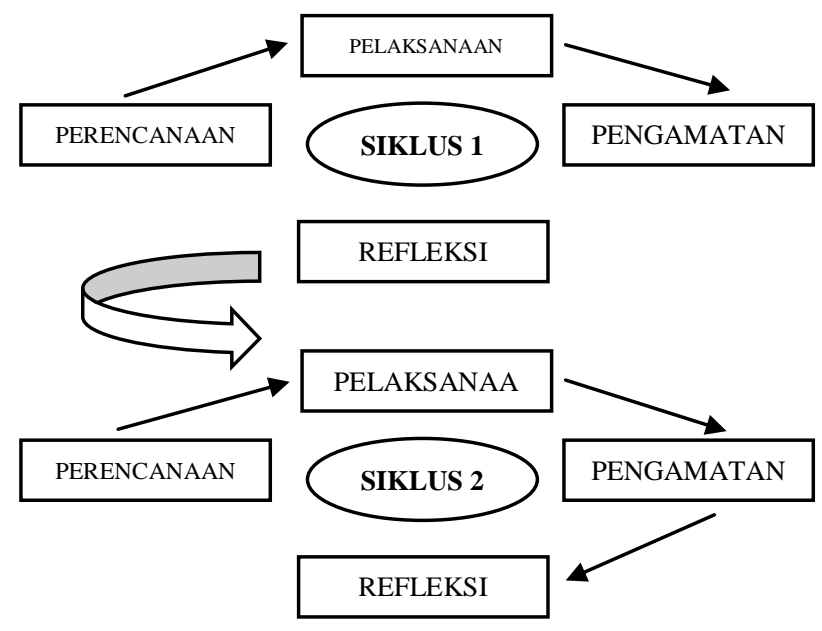

Diagram1 . Prosedur Penelitian

Jenis data yang dikumpulkan meliputi data penyebab aktifitas belajar, data hasil ulangan siswa, dan foto kegiatan siswa. Alat pengumpulan data berupa kuesioner untuk mengungkap aktifitas belajar siswa dalam pembelajaran, lembar observasi untuk mengukur aktifitas siswa dan guru pada saat melaksanakan tindakan kelas, alat evaluasi berupa butir-butir soal tes untuk mengetahui tingkat pemahaman dan penguasaan siswa terhadap materi pelajaran.

Dari hasil penelitian tindakan kelas ini akan diperoleh beberapa data, yang meliputi : (I) aktifitas belajar dan hasil belajar siswa,berupa angket (ii) suasana kegiatan pembelajaran, berupa lembar observasi. (iii) refleksi diri dan perubahanperubahan yang terjadi, berupa tes tertulis. (iv) keterkaitan perencanaan dengan pelaksanaan, berupa kesimpulan.

Pengumpulan data dilaksanakan dengan menggunakan informasi yang diperoleh secara langsung dengan responden pada kelas XI IPA 1. Data yang diperoleh secara langsung dari responden dan populasi berupa data hasil observasi/pengamatan langsung kegiatan pembelajaran, angket, dokumentasi (foto kegiatan dalam pembelajaran) dan hasil dokumen daftar nilai ulangan harian. Jenis data yang dikumpulkan meliputi data aktifitas belajar siswa, data hasil ulangan siswa, dan foto kegiatan siswa. Alat pengumpulan data berupa angket dan lembar observasi untuk mengungkap aktifitas belajar siswa dalam pembelajaran, alat evaluasi berupa butir-butir soal tes untuk mengetahui tingkat pemahaman dan penguasaan siswa terhadap materi pelajaran.

Validasi data dilakukan dengan triangulasi data yng diperoleh dari siswa, peneliti dan kolaborator sehingga diperoleh data yang valid dan akurat. Data kuantitatif dalam penelitian ini merupakan data-data yang diperoleh dalam bentuk angka yaitu data dari hasil ulangan harian yang divalidasi instrumennya. Data kualitatif yaitu data yang diperoleh dari hasil wawancara, observasi, chek list dapat divalidasi melalui triangulasi bersama kolaborator.

Dalam penelitian ini diperoleh dua bentuk data yaitu berupa data kuantitatif dan data kualitatif. Data-data yang telah terkumpul 
kemudian dilakukan analisa untuk mendapatkan kesimpulan. Dalam penelitian ini yang dimaksud data kuantitatif adalah data yang berupa angkaangka hasil ulangan harian, untuk data kuantitatif tehnik analisis data yang dipakai yaitu teknik analisis deskriptif komparatif yaitu dengan membandingkan nilai tes awal dengan nilai tes setelah tindakan pada siklus 1 dan siklus 2. Data kualitatif hasil pengamatan maupun wawancara dianalisis dengan menggunakan analisis diskriptif kualitatif berdasarkan hasil observasi dan refleksi dari kondisi awal sebelum penelitian, setelah tindakan siklus 1, dan siklus ke 2. Analisis kualitatif hal ini dilakukan dengan cara membandingkan antara kegiatan-kegiatan yang dilakukan sebelum tindakan dan setelah dilakukan tindakan dengan model pembelajaran melalui model pembelajaran $P B L$.

Kesimpulan diambil setelah diperoleh informasi yang lengkap dari pelaksanaan pembelajaran dari semua kegiatan siklus ke siklus. Setiap hambatan maupun kemajuan pembelajaran diungkapkan secara detail untuk memperoleh gambaran secara menyeluruh, setelah sampai titik jenuh dengan penerapan model pembelajaran dengan melihat dan menganalisa dari berbagai informasi maka dapat diambil kesimpulan secara menyeluruh hasil pelaksanaan pembelajaran. Validasi data untuk memperoleh kesimpulan yang akurat dan dapat dipertanggungjawabkan dilakukan melalui triangulasi baik triangulasi sumber (wawancara langsung antara guru peneliti, guru kolaborator dan siswa ).
Tabel 1. Indikator Keberhasilan Penelitian

\begin{tabular}{clcc}
\hline No & Aspek & Target & $\begin{array}{c}\text { Teknik } \\
\text { Pengukuran }\end{array}$ \\
\hline 1 & Prestasi Belajar & $\geq 75$ & Ulangan harian \\
\hline 2 & Aktifitas & $\geq 75$ & Angket dan \\
& & & pengamatan \\
\hline
\end{tabular}

Penelitian Tindakan Kelas (PTK) ini terdiri dari dua siklus. Siklus I dilaksanakan 2 kali pertemuan yaitu 4 jam pelajaran, dan siklus II juga 2 kali pertemuan yaitu 4 jam pelajaran. Jadi, untuk menyelesaikan penelitian memerlukan waktu 8 jam pelajaran atau 4 kali pertemuan. PTK dilaksanakan dalam wujud proses pengkajian berdaur (siklis) yang terdiri atas empat tahap, yakni perencanaan, pelaksanaan tindakan, observasi, dan refleksi. Di dalam kenyataannya praktik di lapangan setiap pokok bahasan biasanya tidak akan dapat diselesaikan dalam satu langkah. (Subyantoro, 2009:9)

\section{HASIL DAN PEMBAHASAN}

Pada siklus I, observasi pelaksanaan pembelajaran di lakukan secara kolaboratif bersama teman sejawat. Observasi dilakukan selama pra siklus sampai dengan pelaksanaan tindakan. Berdasarkan observasi ini diperoleh bahwa pada siklus pertama, beberapa siswa atau kelompok diskusi masih terlihat canggung. Berdasarkan hasil wawancara dengan siswa diperoleh bahwa beberapa siswa merasa kurang cocok dengan teman diskusinya. Kebiasaan dalam pergaulan ternyata mempengaruhi kekompakan dan saling pengertian diantara siswa. 
Nilai rata-rata kelas sudah menujukkan peningkatan hasil pembelajaran. Tetapi ketika memperhatikan sebaran nilainya, tampak bahwa hanya beberapa siswa yang mengalami peningkatan siginifikan.

Tabel. 2 Hasil Belajar dan aktifitas pada Siklus I

\begin{tabular}{lcc}
\hline \multicolumn{1}{c}{ Aspek } & $\begin{array}{c}\text { Hasil } \\
\text { Belajar }\end{array}$ & Aktifitas \\
\hline Nilai Rata-rata & 75 & 80 \\
\hline \% Ketuntasan & 66 & 75 \\
\hline
\end{tabular}

Berdasarkan tabel tersebut tampak bahwa rata-rata hasil belajar siswa sudah meningkat yaitu 75, tetapi daya serap ketuntasan belajar baru mencapai $66 \%$ dengan simpangan rata-rata 4,14, sedangkan nilai akifitas belajar siswa mencapai 80 dengan simpangan rata-rata 5,63. Masih tingginya simpangan rata-rata pada hasil belajar dan aktifitas belajar menunjukkan masih bersar perbedaan kemampuan diantara siswa. Hal ini mungkin disebabkan kurang aktifnya sebagian siswa dalam kegiatan diskusi. Siswa menghendaki pembentukan kelompok diskusi bebas sesuai pilihan sendiri, sehingga mereka merasa nyaman dalam berdiskusi. Berdasarkan hal tersebut disimpulkan bahwa guru masih akan mengadakan pembelajaran yang sama untuk siklus berikutnya dengan mengadakan perbaikan beberapa hal, yaitu cara membentuk kelompok belajar, pemberian pengantar / stimulus yang berkaitan dengan materi, dan buku-buku referensi.

Pada siklus 2, observasi pelaksanaan pembelajaran di lakukan secara kolaboratif bersama teman sejawat. Berdasarkan observasi ini diperoleh bahwa siswa sudah mulai aktif dalam kegiatan diskusi kelompok serta pemahaman konsep tentang komposisi fungsi meningkat. Hal ini ditunjukkan dengan dengan banyaknya siswa yang bersedia untuk menyajikan hasil diskusinya di depan kelas serta banyak siswa lain yang menanggapi. Di samping itu tampak bahwa suasana pembelajaran lebih santai dan menyenangkan.

Tabel. 3 Hasil Belajar dan aktifitas pada Siklus 2

\begin{tabular}{lcc}
\hline \multicolumn{1}{c}{ Aspek } & $\begin{array}{c}\text { Hasil } \\
\text { Belajar }\end{array}$ & Aktifitas \\
\hline Nilai Rata-rata & 77 & 82 \\
\hline \% Ketuntasan & 81 & 84 \\
\hline
\end{tabular}

Berdasarkan tabel di atas tampak bahwa rata-rata hasil belajar siswa sudah meningkat yaitu 77 dengan daya serap ketuntasan belajar mencapai $81 \%$ dan simpangan rata-rata 4,28. Sedangkan nilai akifitas belajar siswa mencapai 82 dengan persentase ketuntasan $84 \%$ dan simpangan ratarata 5,56. Kegiatan pembelajaran berbasis masalah yang dilaksanakan peneliti di SMA Negeri 1 Wuryantoro ternyata mampu membangkitkan aktifitas belajar peserta didi dan meningkatkan hasil belajar. Hal ini ditunjukkan dengan peningkatan nilai tes hasil belajar dan angket aktifitas belajar selama kegiatan berlangsung.

Tabel 4. Nilai Rata-rata Hasil Belajar dan Aktifitas Belajar Siswa

\begin{tabular}{llcc}
\hline Variabel & $\begin{array}{c}\text { Pra } \\
\text { Siklus }\end{array}$ & $\begin{array}{c}\text { Siklus } \\
1\end{array}$ & $\begin{array}{c}\text { Siklus } \\
2\end{array}$ \\
\hline Hasil Belajar & 73 & 75 & 77 \\
\hline Aktifitas Belajar & 77 & 80 & 82 \\
\hline
\end{tabular}


Tabel 5. Persentase Ketuntasan Hasil Belajar dan Aktifitas Belajar Siswa

\begin{tabular}{lllc}
\hline Variabel & $\begin{array}{l}\text { Pra } \\
\text { Siklus }\end{array}$ & $\begin{array}{l}\text { Siklus } \\
1\end{array}$ & Siklus 2 \\
\hline Hasil Belajar & 53 & 66 & 81 \\
\hline Aktifitas Belajar & 59 & 75 & 84 \\
\hline
\end{tabular}

Berdasarkan Tabel 4 dan Tabel 5 diperoleh bahwa hasil belajar dan aktifitas belajar siswa meningkat. Hal itu meliput nilai tes/angket mapun persentase ketuntasannya. Dengan demikian sesuai data yang diperoleh dan hasil hasil analisa peneliti bersama kolaborator dan observer, maka diperoleh hasil bahwa model pmbelajaran PBL mampu meningkatkan hasil belajar dan aktifitas belajar siswa di kelas XI IPA 1.

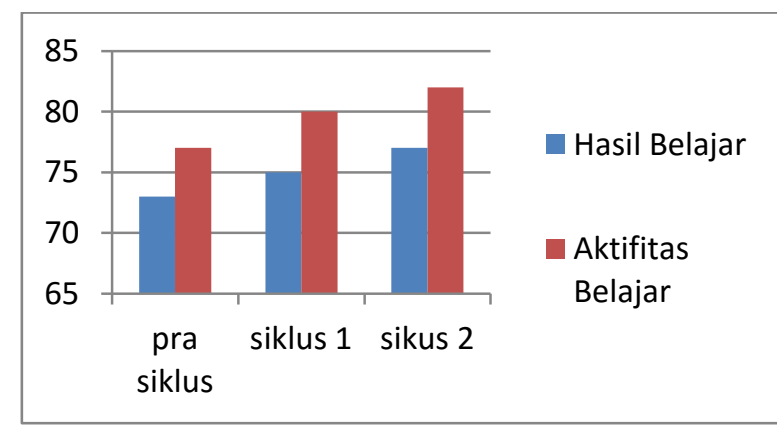

Diagram 2. Nilai Rata-rata Hasil Belajar dan Aktifitas Belajar Siswa

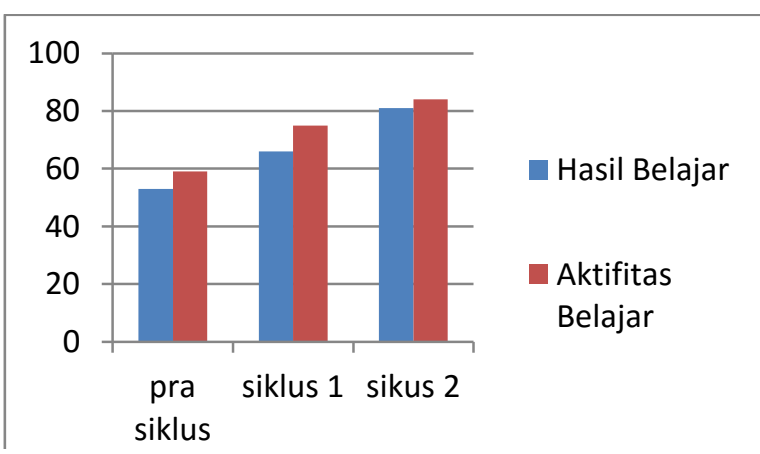

Diagram 3. Persentase Hasil Belajar dan Aktifitas Belajar Siswa

Diagaram 2 dan Diagram 3 menunjukkan bahwa ada kecenderungn hasil belajar dan aktifitas belajar meningkat. Tetapi aktifitas belajar reltif lebih tinggi daripada hasil belajar. Hal mungkin disebabkan siswa mulai nyaman belajar menggunakan model pembelajaran berbasis masalah, tetapi hal yang berkaitan dengan kemampuaan kognitif relatif belum siginifikan. Analisa ini juga diperkuat dengan hasil wawancara dengan guru maupun siswa ataupun hasil pengamatan kolaborator bahwa pada awal diterapkan siswa masih merasa kebingungan, namun setelah tahu langkah-langkahnya ternyata menjadikan proses belajar mengasyikkan dan menyenangkan.

Siswa lebih bersemangat mengikuti pelajaran, karena semakin mudah menerima materi. Hal yang menarik karena untuk memecahkan masalah mencari sendiri berbagai sumber, tidak hanya mengandalkan informasi dari guru. Sehingga dengan cara ini lebih dapat menambah penguasaan materi, sehingga hasil belajar menjadi lebih baik. Beberapa hal masih perlu diperbaiki dalam pembelajaran menggunakan model pembelajaran berbasis masalah, diantaranya persiapan yang lebih matang terkait alokasi waktu, pemilihan masalah, suasana diskusi di kelas, administrasi pembelajaran, dan kemampuan guru dalam memfasilitasi siswa.

Masih tingginya simpangan rata-rata pada hasil belajar dan aktifitas belajar menunjukkan masih besar perbedaan kemampuan diantara siswa yang tentunya tidak mungkin untuk disamakan. Namun demikian kecenderungan peningkatan nilai hasil belajar dan aktifitas belajar menunjukkan bahwa siswa merasa nyaman dalam kegiatan pembelajaran. Kekompakan dan keterbukaan dalam diskusi mampu menghilangkan rasa 
canggung daan malu dalam bertanya sehingga siswa mampu mendapatkan pengalaman belajar yang baru. Kemauan dalam kegiatan presentasi dan menjawab pertanyaan-pertanyaan juga semakin memantapkan siswa terhadap pengetahuan baru yang didapatkan. Selain itu persentase ketuntasan yang sudah lebih dari $75 \%$ menunjukkan bahwa ada peningkatan hasil belajar dan aktifitas belajar siswa.

Pengetahuan tidak dapat dipindahkan begitu saja dari guru ke siswa. Proses pembelajaran bukan transfer knowledge semata, melainkan merupakan pemberian stimulan kepada siswa supaya mampu berpikir kritis, aktif mencari, mengolah, mengkonstruksi, dan menggunakan pengetahuan. Pembelajaran berbasis masalah merupakan sebuah model pembelajaran yang menyajikan masalah kontekstual sehingga merangsang siswa untuk belajar. Dalam kelas yang menerapkan pembelajaran berbasis masalah, siswa bekerja dalam tim untuk memecahkan masalah dunia nyata. Peranan guru dalam model pembelajaran berbasis masalah adalah menyajikan masalah, mengajukan pertanyaan dan memfasilitasi penyelidikan dan dialog.

Masalah yang diberikan ini digunakan untuk mengikat siswa pada rasa ingin tahu pada pembelajaran yang dimaksud. Masalah diberikan kepada siswa, sebelum siswa mempelajari konsep atau materi yang berkenaan dengan masalah yang harus dipecahkan. Kegiatan pembelajaran berbasis masalah yang dilaksanakan peneliti di SMA Negeri 1 Wuryantoro cenderung mampu membangkitkan aktifitas belajar siswa dan meningkatkan hasil belajar. Jika sebelumnya siswa cenderung hanya mendengarkan, memperhatikan, mencatat, dan mengerjakan penjelasan guruyang pada akhirnya kurang mampu memberikan pembelajaran yang bermakna, maka setelah menggunakan model pembelajaran berbasis masalah siswa lebih memahami konsep dalam pembelajaran. Hal ini ditunjukkan dengan peningkatan nilai tes hasil belajar dan angket aktifitas belajar selama kegiatan berlangsung.

\section{KESIMPULAN DAN SARAN}

Berdasarkan kajian pustaka dan hasil penelitian diperoleh kesimpulan 1) aktivitas belajar siswa kelas XI IPA SMAN 1 Wuryantoro pada pokok bahasan Komposisi Fungsi menggunakan model pembelajaran $P B L$ lebih meningkat. Hal ini ditunjukkan dengan peningkatan hasil angket dari pra siklus sebesar 77 , skulus 1 sebesar 80 kemudian siklus 2 sebesar 82, sedangkan persentase ketuntasannya berturut-turut 59, 75, dan 84. Aktifitas belajar meningkat karena siswa mulai menikmati pembelajaran karena materi dikaitkan dengan permasalahan sehari-hari serta siswa aktif berdiskusi dengan temannya sehingga suasana pembelajaran lebih menyenangkan. 2) Model pembelajaran $P B L$ dapat meningkatkan hasil belajar siswa kelas XI IPA SMAN 1 Wuryantoro pada pokok bahasan Komposisi Fungsi. Hal ini ditunjukkan dengan peningkatan hasil tes dari pra siklus sebesar 73, siklus 1 sebesar 75 kemudian siklus 2 sebesar 77. Persentase ketuntasannya berturut-turut 53, 66, dan 81. Hasil belajar meningkat karena siswa mampu mengkonstruki konsep komposisi fungsi setelah menyelesaikan permasalahan sehari-hari yang berkaitan dengan 
konsep komposisi. Ketika dihadapkan pada soalsoal yang abstrak mereka mampu mengolah, mengkonstruksi, dan menyelesaikannya.

Berdasarkan hasil penelitian dan simpulan di atas, maka peneliti mempunyai beberapa saran yang perlu dipertimbangkan, yaitu 1) Guru mencobakan model pembelajaran berbasis masalah untuk materi yang dapat direkayasa sedemikian rupa sehingga dapat dipilih atau ditentukan masalah nyata yang sesuai dengan kompetensi tertentu. 2) Sebelum melaksanakan pembelajaran menggunakan model pembelajaran berbasis masalah, semua perangkat pembelajaran dan alat evaluasi dipersiapkan terlebih dahulu dengan baik.

3) Guru harus pandai menyajikan masalah-masalah dunia nyata sehungga menarik dan mudah dimengerti siswa. 4) Guru mengembangkan tahapan pembelajaran pada model pembelajaran $P B L$ dengan memperbaiki aktifitas pembelajarannya. 5) Guru melakukan penelitian yang sejenis untuk materi atau mata pelajaran yang lain

\section{DAFTAR PUSTAKA}

Abdullah, NI, Tarmizi, R, dan Abu, R. (2010). The Effects of Problem Based Learning on Mathematics Performance and Affective Attributes in Learning Statistics at Form Four Secondary Level. Universiti Putra Malaysia. International Conference on Mathematics Education Research 2010 (ICMER 2010), pp 370-376

Abdurrahman, M. (2003). Pendidikan Bagi Anak Berkesulitan Belajar Cetakan Ke-2. Jakarta : Rineka Cipta

Aqib, Z. (2009). Penelitian Tindakan Kelas untuk Guru. Bandung : Yrama Widya.

Arends, R. (2008). Learning To Teach. New York: McGraw-hill.

Arikunto, S dan Jafar, C. (2004). Evaluasi Program Pendidikan. Jakarta : Bumi Aksara
Bilgin, I, Senocak, E, dan Sozbilir, M. (2009). The Effect of Problem Based Learning Instruction on University Students Performance. Eurasia Journal of Mathematic, Science, and Technology Education, 2009, 5(2) 153-164

Fathurrohman, M. (2015). Model - Model Pembelajaran Inovatif. Jogjakarta :Ar-Ruzz Media

Fermansyah, D. (2005). Matematika Program Ilmu Alam Kelas XI. Bogor : Regina

Hollands, R. (1991) Kamus Matematika (Terjemahan Naipospos Hutauruk). Jakarta : Erlangga

Joyce, B., Weil, M. dan Calhoun, E. (2011). Model of Teaching- Model-Model Pengajaran.

Yogyakarta: Pustaka Pelajar

Padmavathy, R.D. dan Mareesh .K. (2013). Effectiveness of Problem Based Learning In Mathematics. International Multidisciplinary eJournal. Vol-II, Issue-I, Jan-2013, pp 45-51

Purwoto. (2000). Strategi Pembelajaran Matematika. Surakarta : UNS Press

Rahayu, ES dan Nuryata, I. (2010). Pembelajaran Masa Kini. Jakarta Timur : SMKN 7 Jakarta

Rakhmat, C dan Suherdi D. (2001). Evaluasi Pengajaran. Bandung : Maulana

Rusman. (2011). Model-Model Pembelajaran Mengembangkan Profesionalisme Guru. Jakarta : Raja Grafindo

Setiawan. (2008). Strategi Pembelajaran Matematika SMA. Yogyakarta : PPPPTK Matematika

Sheryl MacMath, John Wallace, dan Xiaohong Chi. (2009). Problem-Based Learning in Mathematics: A Tool for Developing Students' Conceptual Knowledge. The Literacy and Numeracy Secretariat. University of Toronto

Slameto. (2003). Belajar dan Faktor-Faktor yang Mempengaruhinya. Jakarta: Rieneka Cipta

Slavin, R. (2005). Cooperative Learning Teori, Riset, dan Praktik. Bandung: Penerbit Nusa Media

Subyantoro. (2009). Penelitian Tindakan Kelas. Semarang : Universitas Diponegoro.

Suminar, EWS. (2011). Eksperimentasi Pembelajaran Matematika dengan Problem Based Learning dan Cooperative Learning Tipe STAD Ditinjau dari Gaya Belajar Siswa. Tesis. Universitas Sebelas Maret Surakarta

Winkel, WS. (1991). Psikologi Pendidikan dan Evaluasi Belajar. Jakarta : Gramedia 